\title{
Microstructural response of InGaN to swift heavy ion irradiation
}

\author{
L.M. Zhang ${ }^{\mathrm{a},{ }^{*}, \text { W. Jiang }}{ }^{\mathrm{b}}$, R.C. Fadanelli ${ }^{\mathrm{c}}$, W.S. Ai ${ }^{\mathrm{a}}$, J.X. Peng ${ }^{\mathrm{a}}$, T.S. Wang ${ }^{\mathrm{a}}$, C.H. Zhang ${ }^{\mathrm{d}}$ \\ a. School of Nuclear Science and Technology, Lanzhou University, Lanzhou, 730000, PR China \\ b. Pacific Northwest National Laboratory, Richland, Washington, 99352, USA \\ c. Instituto de Física, Universidade Federal do Rio Grande do Sul, Porto Alegre, 91500, Brazil \\ d. Institute of Modern Physics, Chinese Academy of Sciences, Lanzhou, 730000, PR China
}

\begin{abstract}
A monocrystalline $\operatorname{In}_{0.18} \mathrm{Ga}_{0.82} \mathrm{~N}$ film of $\sim 275 \mathrm{~nm}$ in thickness grown on a $\mathrm{GaN} / \mathrm{Al}_{2} \mathrm{O}_{3}$ substrate was irradiated with $290 \mathrm{MeV}{ }^{238} \mathrm{U}^{32+}$ ions to a fluence of $1.2 \times 10^{12} \mathrm{~cm}^{-2}$ at room temperature. The irradiated sample was characterized using helium ion microscopy (HIM), Rutherford backscattering spectrometry under ion-channeling conditions (RBS/C), and high-resolution x-ray diffraction (HRXRD). The irradiation leads to formation of ion tracks throughout the thin $\operatorname{In}_{0.18} \mathrm{Ga}_{0.82} \mathrm{~N}$ film and the $3.0 \mu \mathrm{m}$ thick GaN buffer layer. The mean diameter of the tracks in $\operatorname{In}_{0.18} \mathrm{Ga}_{0.82} \mathrm{~N}$ is $\sim 9 \mathrm{~nm}$, as determined by HIM examination. Combination of the HIM and RBS/C data suggests that the $\operatorname{In}_{0.18} \mathrm{Ga}_{0.82} \mathrm{~N}$ material in the track is likely to be highly disordered or fully amorphized. The irradiation induced lattice relaxation in $\operatorname{In}_{0.18} \mathrm{Ga}_{0.82} \mathrm{~N}$ and a distribution of d-spacing of the (0002) planes in $\mathrm{GaN}$ with lattice expansion are observed by HRXRD.
\end{abstract}

Keywords: Swift heavy ion irradiation; Microstructure; InGaN

\section{Introduction}

InGaN is an important semiconductor material that has a variety of electronic and optoelectronic applications, especially in the development of advanced solar photovoltaic devices $[1,2]$. A basic understanding of ion irradiation effects in the semiconductor material is essential to tailor its optical and electrical properties by applying ion-beam techniques, such as ion implantation. The ion-beam-induced

*Corresponding Author. Tel.: +86-931-8913551, FAX: +86-931-8913551

E-mail address: zhanglm@1zu.edu.cn 
radiation damage in $\mathrm{InGaN}$ has been investigated worldwide over the past two decades [3-12]. For heavy-ion irradiation with ion energies ranging from several hundred $\mathrm{keV}$ to several $\mathrm{MeV}$, the radiation resistance of $\operatorname{In}_{x} \mathrm{Ga}_{1-x} \mathrm{~N}(0 \leq x \leq 1)$ to structural amorphization has been found to dramatically decrease with increasing In content $x$ [7-12]. In general, energetic ion induced atomic collision cascades are responsible for defect production and accumulation in crystals, while the simultaneous electronic processes involving heat production from electron-phonon coupling can contribute to defect recovery. In the regimes of intermediate and fast ion velocities, nuclear stopping power $\left(S_{n}\right)$ of ions in matter decreases and electronic stopping power $\left(\mathrm{S}_{\mathrm{e}}\right)$ increases with increasing ion energy. The two processes for damage formation and recovery compete each other to determine the final damage states in crystalline materials during ion irradiation $[13,14]$. Which process dominates depends not only on material properties, but also ion mass and energy [13-15]. For heavy ions with energies on the order of several tens of $\mathrm{MeV}$ or higher (so called "swift heavy ions (SHIs)"), huge electronic energy is deposited in a nanometer-sized volume during their passage in materials. A transient process of local material melting and re-solidification along the ion pathway could occur $[13,16]$. SHI irradiation induced modifications in $\mathrm{GaN}$ have been extensively reported, including ion track formation [17-19], film delamination [17, 20], lattice expansion [21, 22], and degradation in electrical and optical properties [22, 23]. However, there have been much fewer publications in the literature for SHI irradiation studies of InGaN. One example is the observation of reduced photoluminescence from $\mathrm{InGaN} / \mathrm{GaN}$ multiple quantum well structures after $40 \mathrm{MeV}$ I ion irradiation [6]. To date, little is known about the microstructural response of InGaN to SHI irradiation. It is of scientific interest and technical significance to investigate structural changes in InGaN induced by SHI irradiation and compare the results to those from GaN under similar irradiation conditions. This study reports on microstructural changes in a monocrystalline $\operatorname{In}_{0.18} \mathrm{Ga}_{0.82} \mathrm{~N}$ film grown on $\mathrm{GaN} / \mathrm{Al}_{2} \mathrm{O}_{3}$ irradiated with $290 \mathrm{MeV} \mathrm{U}$ ions. 


\section{Experimental}

Using low-pressure metal-organic chemical vapor deposition (LP-MOCVD), a wurtzite InGaN film was epitaxially grown on $c$-plane sapphire substrate with a GaN buffer layer. The growth temperatures for the $\mathrm{InGaN}$ film and $\mathrm{GaN}$ buffer layer are 700 and $1050{ }^{\circ} \mathrm{C}$, respectively. The In content $x$ in $\operatorname{In}_{x} \mathrm{Ga}_{1-x} \mathrm{~N}$ is $0.18 \pm 0.01$, as determined by Rutherford backscattering spectrometry (RBS). The thickness values of the $\mathrm{In}_{0.18} \mathrm{Ga}_{0.82} \mathrm{~N}$ film and $\mathrm{GaN}$ buffer layer were determined by cross-sectional HIM to be $\sim 275 \mathrm{~nm}$ and $\sim 3.0 \mu \mathrm{m}$, respectively. Irradiation of the sample with $290 \mathrm{MeV}$ ${ }^{238} \mathrm{U}^{32+}$ ions was performed at the irradiation end-station of the sector focus cyclotron in the National Laboratory of Heavy-Ion Accelerator in Lanzhou, P.R. China. The irradiation was conducted at nominally room temperature and normal incidence to an ion fluence of $1.2 \times 10^{12} \mathrm{~cm}^{-2}$ with a beam flux of $\sim 1 \times 10^{9} \mathrm{~cm}^{-2} \mathrm{~s}^{-1}$. According to calculations using the SRIM code [24], the $S_{e}$ and $S_{n}$ of $290 \mathrm{MeV}^{238} \mathrm{U}$ ions in $\mathrm{In}_{0.18} \mathrm{Ga}_{0.82} \mathrm{~N}$ are 40.5 and $0.35 \mathrm{keV} / \mathrm{nm}$, respectively, and the ion projected range in the sample is $\sim 13.5 \mu \mathrm{m}$. The mean equilibrium charge state of $290 \mathrm{MeV} \mathrm{U}$ ions in $\mathrm{In}_{0.18} \mathrm{Ga}_{0.82} \mathrm{~N}$ is $40^{+}$based on the calculation using the CasP 5.0 code [25]. The value is significantly higher than the initial ion charge state of $32^{+}$. These $U$ ions at 1.2 $\mathrm{MeV} /$ nucleon are expected to attain charge state equilibrium within a few tens of nanometers $(<50 \mathrm{~nm})$ in $\operatorname{In}_{0.18} \mathrm{Ga}_{0.82} \mathrm{~N}$ [26]. Because $\mathrm{S}_{\mathrm{e}}$ increases with increasing ion effective charge in the energy range of this study [25, 27], whose value is close to the mean charge in the equilibrium state [28], the $S_{\mathrm{e}}$ of the $\mathrm{U}$ ions near the sample surface prior to charge-state equilibrium is expected to be significantly smaller than that at larger depths, where it remains nearly unchanged $(\sim 40 \mathrm{keV} / \mathrm{nm})$ for the ions traversing in the thin $\operatorname{In}_{0.18} \mathrm{Ga}_{0.82} \mathrm{~N}$ and $\mathrm{GaN}$ layers in this study.

HIM examination of the irradiated sample was carried out at an operation voltage of $25 \mathrm{kV}$ with a probe current of $0.6 \mathrm{pA}$ and a dwell time of $50 \mu$ s at each pixel within the Environmental Molecular Science Laboratory at the Pacific Northwest National Laboratory in the USA. The overall crystal damage in the irradiated $\operatorname{In}_{0.18} \mathrm{Ga}_{0.82} \mathrm{~N}$ was 
evaluated by RBS/C at the Ion Implantation Laboratory of the Federal University of Rio Grande do Sul in Brazil. The RBS/C measurements were performed with 1.5 $\mathrm{MeV} \mathrm{He}$ beam incident along the <0001>-axial direction of $\operatorname{In}_{0.18} \mathrm{Ga}_{0.82} \mathrm{~N}$ at a backscattering angle of $170^{\circ}$. The backscattering yields have an uncertainty of $\sim 7 \%$, which mainly originated from the inaccuracy of the current integration. In addition, HRXRD was also performed using a Bruker D8 diffractometer at the Suzhou Institute of Nano-Tech and Nano-Bionics, Chinese Academy of Sciences. Symmetric scans around the (0002) planes of both $\mathrm{In}_{0.18} \mathrm{Ga}_{0.82} \mathrm{~N}$ and $\mathrm{GaN}$ single crystals were made in the triple-axis mode with an angular resolution of $0.005^{\circ}$.

\section{Results and Discussion}

\subsection{Ion track and structure}

Cross-sectional HIM images for a freshly cleaved surface of the $\mathrm{U}$ ion irradiated $\mathrm{In}_{0.18} \mathrm{Ga}_{0.82} \mathrm{~N} / \mathrm{GaN} / \mathrm{Al}_{2} \mathrm{O}_{3}$ sample are shown in Fig. 1. For comparison, a cross-sectional HIM (Fig. 1(a)) image from a virgin sample is also shown in the figure. After irradiation, ion tracks throughout the $\mathrm{In}_{0.18} \mathrm{Ga}_{0.82} \mathrm{~N}$ and $\mathrm{GaN}$ layers are observed by HIM. Overlapping of the ion tracks occurs at the fluence of $1.2 \times 10^{12} \mathrm{~cm}^{-2}$. In the higher-resolution HIM image (Fig. 1(c)), the white lines normal to the sample surface are the individual ion tracks in the $\operatorname{In}_{0.18} \mathrm{Ga}_{0.82} \mathrm{~N}$ film, some of which are indicated by arrows in the figure. The mean diameter of the tracks in $\operatorname{In}_{0.18} \mathrm{Ga}_{0.82} \mathrm{~N}$ is $\sim 9 \mathrm{~nm}$. The track diameter for $\mathrm{GaN}$ is almost the same, which is consistent with the value of $\sim 10$ $\mathrm{nm}$ observed by Kucheyev et al. [17] in GaN under a similar irradiation condition with $200 \mathrm{MeV} \mathrm{Au}$ ions at room temperature. However, further studies of the multilayered sample in Fig. 1 based on a plan-view examination of high-resolution transmission electron microscopy (HRTEM) may be needed to confirm the results. 

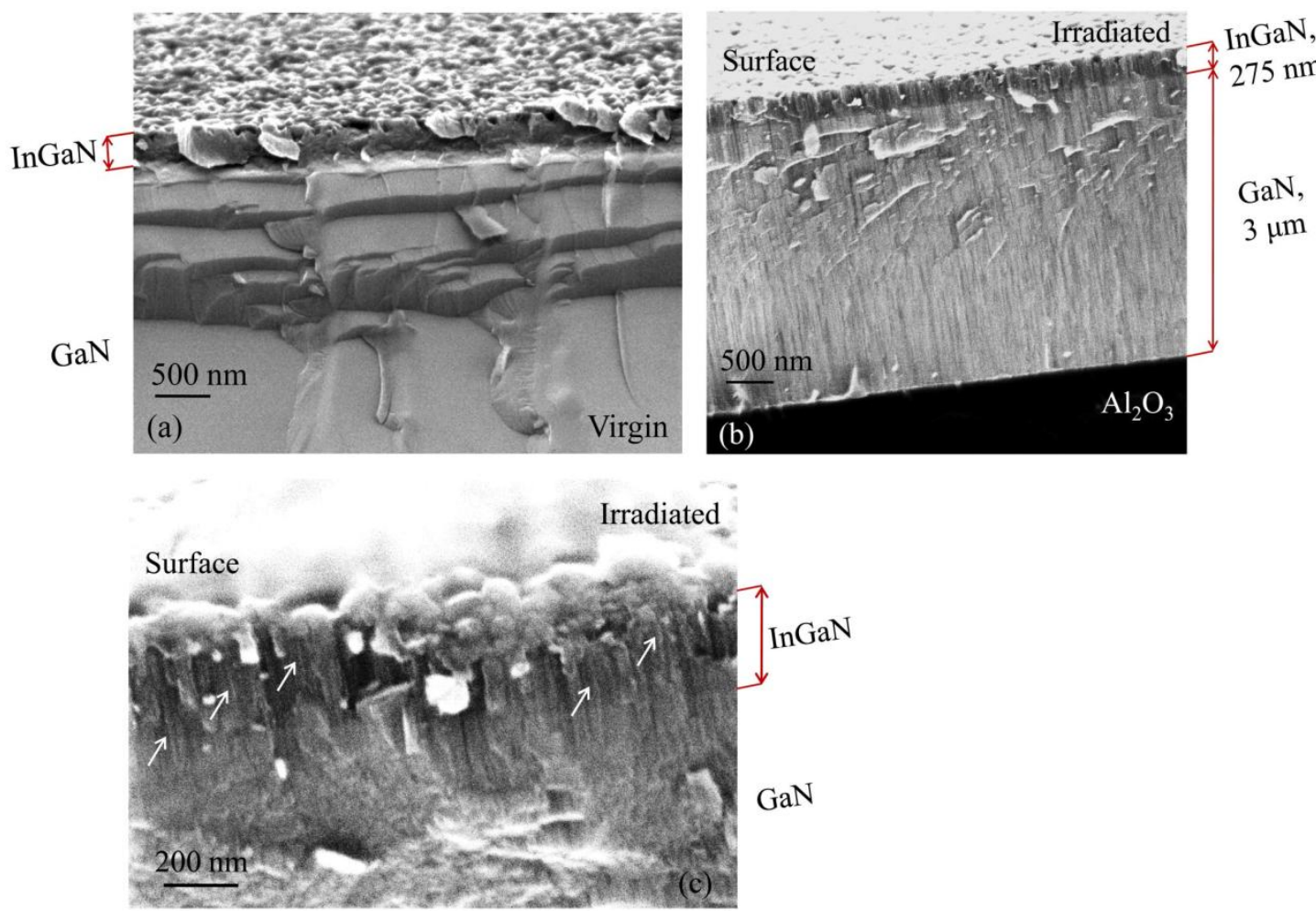

Fig. 1. (a) Cross-sectional $\mathrm{HIM}$ image for a virgin $\mathrm{In}_{0.18} \mathrm{Ga}_{0.82} \mathrm{~N} / \mathrm{GaN} / \mathrm{Al}_{2} \mathrm{O}_{3}$ sample; Cross-sectional HIM images for (b) a similar sample irradiated with $290 \mathrm{MeV}$ U ions to a fluence of $1.2 \times 10^{12} \mathrm{~cm}^{-2}$ at room temperature, and (c) a magnified view of the ion tracks in $\operatorname{In}_{0.18} \mathrm{Ga}_{0.82} \mathrm{~N}$ and GaN.

The formation mechanism for SHI tracks in semiconductor materials has been described by the thermal spike model $[16,29,30]$. This model assumes that due to the intense electronic excitation by SHIs, a molten region around the ion trajectory could be created via electron-phonon coupling, and a modified structure (i.e., ion track) could be formed upon a rapid re-solidification of the molten region. Obviously, a certain $\mathrm{S}_{\mathrm{e}}$ threshold for SHIs in a material is required to create ion tracks; otherwise, damage recovery may become a dominant process [14]. The $S_{\mathrm{e}}$ threshold depends on the chemical and thermal properties, and varies for different materials. Also, radiation temperature and ion velocity can influence the SHI track formation $[15,31]$. The $S_{e}$ threshold for GaN was found to be between 22.8 and $28.3 \mathrm{keV} / \mathrm{nm}$ [19]. The $\mathrm{S}_{\mathrm{e}}$ threshold for InN has not yet been reported to our best knowledge. However, InN was found to be more susceptible to SHI irradiations than $\mathrm{GaN}$ [18]. Ion tracks of $\sim 8 \mathrm{~nm}$ 
in diameter were produced in $\mathrm{InN}$ when irradiated at room temperature with $132 \mathrm{MeV}$ $\mathrm{Pb}$ ions [18], where the $\mathrm{S}_{\mathrm{e}}$ is $24.9 \mathrm{keV} / \mathrm{nm}$ based on the SRIM calculation. This indicates that the $\mathrm{S}_{\mathrm{e}}$ threshold for SHI track formation in $\mathrm{InN}$ is not higher than 24.9 $\mathrm{keV} / \mathrm{nm}$. As a ternary alloy, $\operatorname{In}_{x} \mathrm{Ga}_{1-x} \mathrm{~N}$ has a $\mathrm{S}_{\mathrm{e}}$ threshold that should be between those of $\mathrm{GaN}$ and $\mathrm{InN}$, i.e. not higher than $28.3 \mathrm{keV} / \mathrm{nm}$. For this study of $290 \mathrm{MeV} \mathrm{U}$ ion irradiation of $\mathrm{In}_{0.18} \mathrm{Ga}_{0.82} \mathrm{~N} / \mathrm{GaN} / \mathrm{Al}_{2} \mathrm{O}_{3}$, the mean $\mathrm{S}_{\mathrm{e}}$ value in the top two layers from the SRIM calculation is $\sim 40 \mathrm{keV} / \mathrm{nm}$, and hence $\mathrm{U}$ ion tracks are expected in both $\mathrm{In}_{0.18} \mathrm{Ga}_{0.82} \mathrm{~N}$ and $\mathrm{GaN}$, as shown by the HIM images.

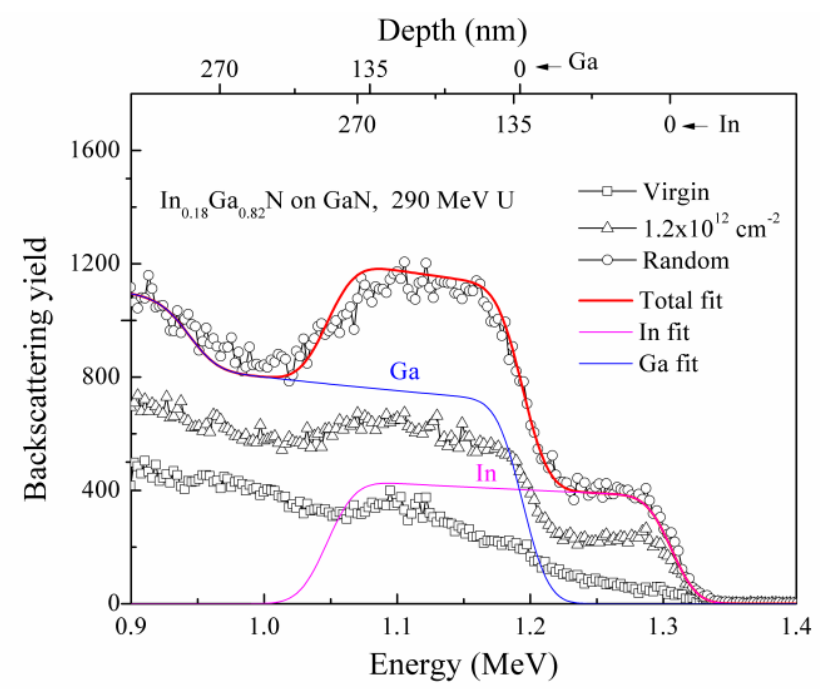

Fig. 2. RBS/C spectra for $\mathrm{In}_{0.18} \mathrm{Ga}_{0.82} \mathrm{~N} / \mathrm{GaN} / \mathrm{Al}_{2} \mathrm{O}_{3}$ before and after $290 \mathrm{MeV} \mathrm{U}$ ion irradiation to a fluence of $1.2 \times 10^{12} \mathrm{~cm}^{-2}$ at room temperature. The line curves are the fitting results of In, Ga and their combined contributions to the random spectrum using the SIMNRA code.

Fig. 2 shows the <0001>-aligned RBS spectra together with the random spectrum for the $\operatorname{In}_{0.18} \mathrm{Ga}_{0.82} \mathrm{~N} / \mathrm{GaN} / \mathrm{Al}_{2} \mathrm{O}_{3}$ sample before and after the $\mathrm{U}$ ion irradiation. Also included in the figure are the fitting results of In, Ga and their combined contributions to the random spectrum using SIMNRA 6.0 code [32]. According to the data fit, the backscattering spectra from the In and Ga sublattices are partly overlapped because of the film thickness. The depth scales of the In and Ga sublattices, determined separately by a numerical method [33] using the He stopping power from the SRIM database, are presented on the top axis of Fig. 2. For the random spectrum, the rear In edge from the $\operatorname{In}_{0.18} \mathrm{Ga}_{0.82} \mathrm{~N}$ film (backscattering energy 
from 1.0 to $1.1 \mathrm{MeV}$ ) shows a gradual slope, suggesting possible interfacial diffusion of In into the $\mathrm{GaN}$ layer. The minimum backscattering yield $\left(\chi_{\min }\right)$ for the virgin $\mathrm{In}_{0.18} \mathrm{Ga}_{0.82} \mathrm{~N}$ is $\sim 20 \%$, which is calculated from the yield ratio of the channeling to random spectrum in a small depth region from $\sim 45$ to $75 \mathrm{~nm}$ just below the surface. The result suggests that there is a pre-existing defect concentration in $\operatorname{In}_{0.18} \mathrm{Ga}_{0.82} \mathrm{~N}$, which could be attributed, in part, to the large lattice mismatch between $\mathrm{GaN}$ and $\mathrm{InN}$ (11-13\%) [1]. After U ion irradiation, the RBS/C yield increases noticeably, indicating an increase in the degree of lattice disorder in the $\operatorname{In}_{0.18} \mathrm{Ga}_{0.82} \mathrm{~N}$ film. The atomic displacement rate in the $\mathrm{U}$-irradiated $\mathrm{In}_{0.18} \mathrm{Ga}_{0.82} \mathrm{~N}$ induced by the ballistic collision process was calculated using the SRIM code [24] under the full-damage cascade mode, with assumptions that the threshold displacement energies for all the sublattices in $\mathrm{In}_{0.18} \mathrm{Ga}_{0.82} \mathrm{~N}$ are $25 \mathrm{eV}$ and the material density is $6.27 \mathrm{~g} / \mathrm{cm}^{3}$. The dose in displacements per atom (dpa) is estimated to be only $\sim 4.5 \times 10^{-4}$ throughout the $\mathrm{In}_{0.18} \mathrm{Ga}_{0.82} \mathrm{~N}$ film thickness at the ion fluence of $1.2 \times 10^{12} \mathrm{~cm}^{-2}$, which is expected to produce little damage in the film [9]. Therefore, it is evident that for the swift $U$ ion irradiation, electronic energy deposition rather than ballistic collision is the dominant process for structural modification in $\operatorname{In}_{0.18} \mathrm{Ga}_{0.82} \mathrm{~N}$.

Assuming ion tracks are cylindrical in shape with the axis parallel to the normal of the sample surface, the fraction of the total area covered by the ion tracks on the sample surface, $S_{d}$, can be estimated by Poisson equation [34],

$$
S_{d}=1-\exp \left(-\pi d^{2} \Phi / 4\right)
$$

where $d$ is the track diameter and $\Phi$ is the ion fluence. Taking $d=9 \mathrm{~nm}$ for the $\mathrm{U}$ ion track in $\mathrm{In}_{0.18} \mathrm{Ga}_{0.82} \mathrm{~N}$ as observed by HIM in Fig. 1(c), the $S_{d}$ value is estimated from Eq. (1) to be $\sim 53 \%$ at the fluence of $1.2 \times 10^{12} \mathrm{~cm}^{-2}$. If we further assume the material inside the ion track is highly disordered or fully amorphized and the rest of the area $(\sim 47 \%)$ outside the track is essentially intact with $\chi_{\min } \approx 20 \%$, the ratio of the RBS/C to random yields for the In sublattice in the irradiated $\operatorname{In}_{0.18} \mathrm{Ga}_{0.82} \mathrm{~N}$ should be $\sim 62 \%$ near the surface region. From Fig. 2, this ratio is estimated to be $\sim 56 \%$ in the same depth 
region where $\chi_{\min }$ was calculated. The consistency between the two ratio values suggests that lattice structure within the ion tracks in $\operatorname{In}_{0.18} \mathrm{Ga}_{0.82} \mathrm{~N}$ is likely to be highly disordered or fully amorphized.

\subsection{Lattice expansion}

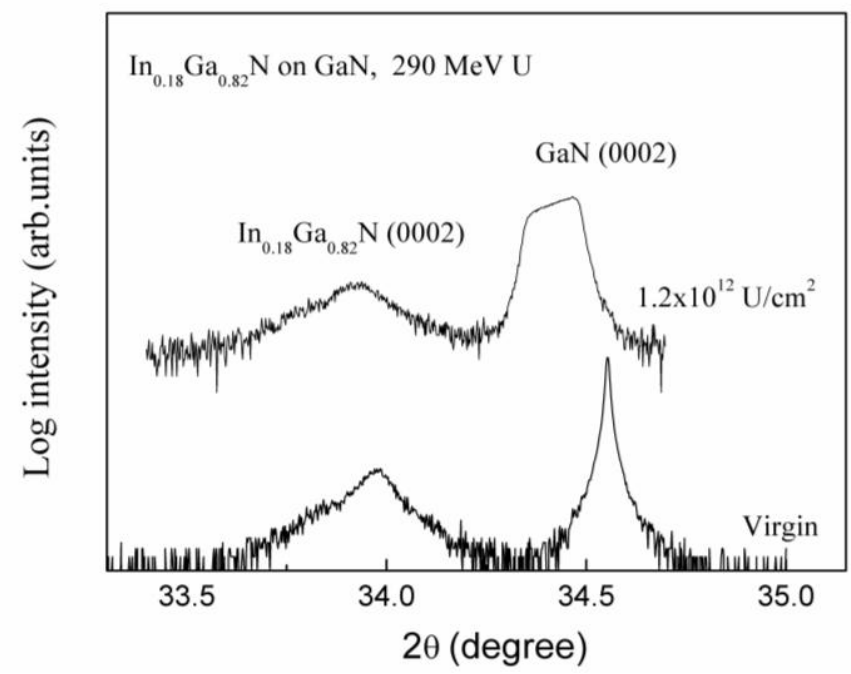

Fig. 3. HRXRD spectra for $\mathrm{In}_{0.18} \mathrm{Ga}_{0.82} \mathrm{~N} / \mathrm{GaN} / \mathrm{Al}_{2} \mathrm{O}_{3}$ before and after $290 \mathrm{MeV} \mathrm{U}$ ion irradiation at room temperature to a fluence of $1.2 \times 10^{12} \mathrm{~cm}^{-2}$.

Fig. 3 shows the HRXRD spectra of the $\mathrm{In}_{0.18} \mathrm{Ga}_{0.82} \mathrm{~N} / \mathrm{GaN} / \mathrm{Al}_{2} \mathrm{O}_{3}$ sample before and after the $\mathrm{U}$ ion irradiation. The relative intensity of $\operatorname{In}_{0.18} \mathrm{Ga}_{0.82} \mathrm{~N}$ (0002) peak decreases after irradiation, suggesting that a portion of the material is highly disordered or amorphized, which is consistent with the RBS/C results. The peak positions of the virgin $\operatorname{In}_{0.18} \mathrm{Ga}_{0.82} \mathrm{~N}$ and $\mathrm{GaN}(0002)$ planes are located at $33.98^{\circ}$ and $34.55^{\circ}$, respectively. The lattice parameters $c$ of the virgin $\operatorname{In}_{0.18} \mathrm{Ga}_{0.82} \mathrm{~N}$ and $\mathrm{GaN}$ deduced from the XRD peaks are 0.5272 and $0.5188 \mathrm{~nm}$, respectively, in comparison to the corresponding database values of 0.5279 and $0.5186 \mathrm{~nm}$ (PDF\#50-0792), respectively. The database value for $\operatorname{In}_{0.18} \mathrm{Ga}_{0.82} \mathrm{~N}$ is obtained by applying Vegard's law [35] with the assumption that the lattice parameter $c$ of $\mathrm{InN}$ is $0.5703 \mathrm{~nm}$ (PDF\#50-1239). After $U$ ion irradiation, the $\operatorname{In}_{0.18} \mathrm{Ga}_{0.82} \mathrm{~N}$ (0002) peak shifts from $33.98^{\circ}$ to $33.93^{\circ}$, and the peak width increases. The deduced lattice parameter $c$ of the irradiated $\mathrm{In}_{0.18} \mathrm{Ga}_{0.82} \mathrm{~N}$ is $0.5280 \mathrm{~nm}$, which is very close to the database value of 
perfect $\mathrm{In}_{0.18} \mathrm{Ga}_{0.82} \mathrm{~N}$ crystal without lattice strains. This suggests that the $\mathrm{U}$ ion irradiation results in lattice relaxation with lattice expansion in the $\operatorname{In}_{0.18} \mathrm{Ga}_{0.82} \mathrm{~N}$ film. In our recent study [11] of similar $\operatorname{In}_{0.18} \mathrm{Ga}_{0.82} \mathrm{~N}$ samples irradiated with several $\mathrm{MeV}$ heavy ions, much more significant lattice expansion was observed in the irradiated films. The lattice parameter $c$ of $\operatorname{In}_{0.18} \mathrm{Ga}_{0.82} \mathrm{~N}$ in that study [11] increases to 0.5306 $\mathrm{nm}$ when irradiated with $4 \mathrm{MeV} \mathrm{Kr}$ ions to a dose of $8.3 \times 10^{-2}$ dpa, with the corresponding lattice expansion rate being $\sim 5$ times larger than that induced by 290 $\mathrm{MeV} \mathrm{U}$ ion irradiation to the dose of $4.5 \times 10^{-4} \mathrm{dpa}$. On the other hand, the relative In disorder in the near-surface of the $\mathrm{Kr}$-irradiated $\mathrm{In}_{0.18} \mathrm{Ga}_{0.82} \mathrm{~N}$ is $19 \%$, which is much smaller than the corresponding value of $\sim 43 \%$ obtained from the U-irradiated film. The detailed calculation of the relative In disorder can be referred to Ref. [11]. In fact, the damage states are different in the $\mathrm{Kr}$ - and $\mathrm{U}$-irradiated films. In the case of $4 \mathrm{MeV}$ $\mathrm{Kr}$ ion irradiation, point defects and/or point defect clusters are initially produced in the film via elastic collision cascades. The point defects are distributed homogeneously over the irradiated film and accumulate gradually with increasing ion fluence to form more complex defects (e.g., planar defect clusters), until full amorphization of the film occurs. Significant lattice expansion of the film can be induced by accumulation of point defects, such as interstitials [11]. However, for 290 $\mathrm{MeV} \mathrm{U}$ ion irradiation, highly disordered or fully amorphized ion tracks could be produced directly in the film. There should be weak or no XRD intensities from the material in the ion tracks. Thus, the $\operatorname{In}_{0.18} \mathrm{Ga}_{0.82} \mathrm{~N}$ peak in the U-irradiated HRXRD spectrum is mainly from the lightly damaged or undamaged region of the irradiated film. According to Eq. (1), $47 \%$ region of the film remains undamaged after the $U$ ion irradiation to the fluence of $1.2 \times 10^{12} \mathrm{~cm}^{-2}$. Lattice expansion and relaxation are expected in the undamaged region due to the presence of nearby ion tracks, which leads to the shift of the $\mathrm{In}_{0.18} \mathrm{Ga}_{0.82} \mathrm{~N}$ reflection peak (Fig. 3).

Like $\mathrm{In}_{0.18} \mathrm{Ga}_{0.82} \mathrm{~N}$, the $\mathrm{GaN}$ (0002) peak also shifts towards smaller angles after the $\mathrm{U}$ ion irradiation, indicating an irradiation-induced lattice expansion in $\mathrm{GaN}$, which was also observed in some other SHI-irradiated GaN [21, 22]. However, in 
contrast to $\operatorname{In}_{0.18} \mathrm{Ga}_{0.82} \mathrm{~N}$, the irradiated $\mathrm{GaN}$ peak broadens apparently towards smaller angles, indicating a distribution of expanded d-spacing of the (0002) planes in GaN. This implies a different damage structure in $\mathrm{GaN}$ induced by the $\mathrm{U}$ ion irradiation as compared to that in $\operatorname{In}_{0.18} \mathrm{Ga}_{0.82} \mathrm{~N}$, which should be associated with the different melting temperature and band gap values of $\mathrm{GaN}$ and $\operatorname{In}_{0.18} \mathrm{Ga}_{0.82} \mathrm{~N}[36,37]$. Kucheyev et al. investigated the irradiation of $200 \mathrm{MeV}$ Au ions in GaN [17], where the $\mathrm{S}_{\mathrm{e}}(34.3 \mathrm{keV} / \mathrm{nm})$ and ion velocity $(\sim 1.0 \mathrm{MeV} /$ nucleon) are close to those for 290 $\mathrm{MeV} \mathrm{U}$ ions in GaN investigated in this study. The HRTEM results show that the material in the induced ion track is not fully amorphized, but the irradiated film consists of planar defects. The planar defects may result in a distribution of d-spacing of the (0002) planes in $\mathrm{GaN}$, responsible for the broadening of the $\mathrm{GaN}$ peak observed in Fig. 3.

\section{Conclusion}

Microstructural response of $\operatorname{In}_{0.18} \mathrm{Ga}_{0.82} \mathrm{~N}$ film grown on a $\mathrm{GaN} / \mathrm{Al}_{2} \mathrm{O}_{3}$ substrate to $290 \mathrm{MeV}$ U ion irradiation at room temperature has been investigated using combined methods of HIM, RBS/C and HRXRD. Ion tracks throughout the $\operatorname{In}_{0.18} \mathrm{Ga}_{0.82} \mathrm{~N}$ and GaN layers are induced by the irradiation. For $\operatorname{In}_{0.18} \mathrm{Ga}_{0.82} \mathrm{~N}$, the mean diameter of the ion tracks is $\sim 9 \mathrm{~nm}$, and the material in the ion tracks is likely to be highly disordered or fully amorphized. The irradiation results in lattice relaxation with lattice expansion in the $\operatorname{In}_{0.18} \mathrm{Ga}_{0.82} \mathrm{~N}$ film, and a distribution of expanded d-spacing of the (0002) planes in the GaN sublayer. Further theoretical simulations based on the thermal spike model are needed to clarify the influence of material properties, such as band gap width and melting temperature, on the formation of ion tracks in the nitride semiconductors.

\section{Acknowledgments}

This work was supported by the National Natural Science Foundation of China (Grant No. 11305081) and the Fundamental Research Funds for the Central Universities 
(Grant No. lzujbky-2016-28). A part of the research was performed under a general proposal at the Environmental Molecular Sciences Laboratory (EMSL), a national scientific user facility sponsored by DOE's Office of Biological and Environmental Research and located at the Pacific Northwest National Laboratory (PNNL). L.M. Zhang was financially supported by China Scholarship Council during his visit to PNNL.

\section{References}

[1] D.V.P. Mclaughlin, J.M. Pearce, Metall. Mater. Trans. A 44A (2013) 1947-1954.

[2] X. Chen, K.D. Matthews, D. Hao, W.J. Schaff, L.F. Eastman, Phys. Stat. Sol. (a) 205 (2008)1103-1105.

[3] J. Wu, W. Walukiewicz, K.M. Yu, W. Shan, J.W. Ager III, E.E. Haller, H. Lu, W.J. Schaff, W.K. Metzger, S. Kurtz, J. Appl. Phys. 94 (2003) 6477-6482.

[4] H. Kim, J. Kim, F. Ren, S. Jang, J. Vac. Sci. Technol. B 28 (2010) 27-29.

[5] R. Khanna, S.Y. Han, S.J. Pearton, D. Schoenfeld, W.V. Schoenfeld, F. Ren, Appl. Phys. Lett. 87 (2005)212107.

[6] M. Ali, O. Svensk, Z. Zhen, S. Suihkonen, P.T. Törmä, H. Lipsanen, M. Sopanen, K. Hjort, J. Jensen, Physica B 404 (2009) 4925-4928.

[7] S.O. Kucheyev, J.S. Williams, J. Zou, S.J. Pearton, Y. Nakagawa, Appl. Phys. Lett. 79 (2001) 602-604.

[8] E. Wendler, W. Wesch, E. Alves, A. Kamarou, Nucl. Instr. Meth. B 218 (2004) 36-41.

[9] S.O. Kucheyev, J.S. Williams, J. Zou, C. Jagadish, J. Appl. Phys. 95 (2004) 3048-3054.

[10] L.M. Zhang, W. Jiang, A. Dissanayake, J.X. Peng, W.S. Ai, J.D. Zhang, Z. Zhu, T.S. Wang, V. Shutthanandan, J. Appl. Phys. 119 (2016) 245704.

[11] L.M. Zhang, R.C. Fadanelli, P. Hu, J.T. Zhao, T.S. Wang, C.H. Zhang, Nucl. Instr. Meth. B 356-357 (2015) 53-56.

[12] L.M. Zhang, C.X. Li, J.T. Zhao, K.J. Yang, G.F. Zhang, T.S. Wang, C.H. Zhang, Nucl. Instr. Meth. B 305 (2013) 1-4.

[13] W. Jiang, R. Devanathan, C.J. Sundgren, M. Ishimaru, K. Sato, T. Varga, S. Manandhar, A. Benyagoub, Acta Mater. 61 (2013) 7904-7916.

[14] A. Kamarou, W. Wesch, E. Wendler, S. Klaumünzer, Nucl. Instr. Meth. B 225 
(2004) 129-135.

[15] W. Wesch, E. Wendler, C.S. Schnohr, Nucl. Instr. Meth. B 277 (2012) 58-69.

[16] M. Toulemonde, E. Paumier, C. Dufour, Radiat. Eff. Defects Solids. 126 (1993) 201.

[17] S.O. Kucheyev, H. Timmers, J. Zou, J.S. Williams, C. Jagadish, G. Li, J. Appl. Phys. 95 (2004) 5360-5365.

[18] S. Mansouri, P. Marie, C. Dufour, G. Nouet, I. Monnet, H. Lebius, Nucl. Instr. Meth. B 266 (2008) 2814-2818.

[19] M. Karlušić, R. Kozubek, H. Lebius, B Ban-d'Etat, R.A. Wihelm, M. Buljan, Z. Siketić, F. Scholz, T. Meisch, M. Jakšić, S. Bernstorff, M. Schleberger, B. Šantić, J. Phys. D: Appl. Phys. 48 (2015) 325304.

[20] C.H. Zhang, Y. Song, Y.M. Sun, H. Chen, Y.T. Yang, L.H. Zhou, Y.F. Jin, Nucl. Instr. Meth. B 256 (2007) 199-206.

[21] L.M. Zhang, C.H. Zhang, C.X. Li, Y. Song, T.S. Wang, Eur. Phys. J. Appl. Phys. 59 (2012) 30101.

[22] J. Gou, L.Q. Zhang, C.H. Zhang, Y. Song, Y.T. Yang, J.J. Li, Y.C. Meng, H.X. Li, Nucl. Instr. Meth. B 307 (2013) 89-92.

[23] N. Sathish, S. Dhamodaran, A.P. Pathak, M. Ghanashyam Krishna, S.A. Khan, D.K. Avasthi, A. Pandey, R. Muralidharan, G. Li, C. Jagadish, Nucl. Instr. Meth. B 256 (2007) 281-287.

[24] J.F. Ziegler, J.P. Biersack, U. Littmark, The Stopping and Range of Ions in Solids, Pergaman Press, New York, 1985; SRIM v.2008, http://www.srim.org.

[25] G. Schiwietz, K. Czerski, M. Roth, F. Staufenbiel, P.L. Grande, Nucl. Instr. Meth. B 226 (2004) 683-704; CasPv.5.0, http://www.casp-program.org.

[26] A. Kamarou, E. Wendler, W. Wesch, J. Appl. Phys. 97 (2005) 123532.

[27] P. Sigmund, A. Schinner, Nucl. Instr. Meth. B (2015), in press, http://dx.doi.org/10.1016/j.nimb.2015.12.041.

[28] W. Jiang, R. Grötzschel, W. Pilz, B. Schmidt, W. Möller, Phys. Rev. B 59 (1999) 226-234.

[29] M. Toulemonde, C. Dufour, E. Paumier, Phys. Rev. B 46 (1992) 14362-14369.

[30] A. Kamarou, W. Wesch, E. Wendler, A. Undisz, M. Rettenmayr, Phys. Rev. B 73 (2006) 184107.

[31] H. Dammak, A. Dunlop, D. Lesueur, A. Brunelle, S. Della-Negra, Y. Le Beyec, Phys. Rev. Lett. 74 (1995) 1135-1138. 
[32] M. Mayer, SIMNRA v.6.0, http://home.rzg.mpg.de/mam/.

[33] W.K. Chu, J.W. Mayer, M.A. Nicolet, Backscattering Spectrometry, Academic Press, Orlando, 1978, Page 87.

[34] J.F. Gibbons, Proc. IEEE 60 (1972) 1062-1096.

[35] F.K. Yam, Z. Hassan, Superlatt. Microstruct. 43 (2008) 1-23.

[36] A. Meftah, J.M. Costantini, N. Khalfaoui, S. Boudjadar, J.P. Stoquert, F. Studer, M. Toulemonde, Nucl. Instr. Meth. B 237 (2005) 563-574.

[37] M. Toulemonde, Ch. Dufour, A. Meftah, E. Paumier, Nucl. Instr. Meth. B 166-167 (2000) 903-912. 